Basic Values, Ideological Self-Placement, and Voting : A Cross-Cultural Study

\title{
Caprara, Gian Vittorio
}

2017-10

Caprara, G V , Vecchione , M , Schwartz , S H , Schoen , H , Bain , P G , Silvester , J , Cieciuch, J , Pavlopoulos , V , Bianchi , G , Kirmanoglu , H, Baslevent , C, Mamali , C , Manzi , J , Katayama, M , Posnova , T , Tabernero , C , Torres , C , Verkasalo, M , Lonnqvist, J-E , Vondrakova, E \& Giovanna Caprara, M 2017 , ' Basic Values, Ideological Self-Placement, and Voting : A Cross-Cultural Study ' , Cross-Cultural Research, vol. 51 , no. 4 , pp. 388-411 . https://doi.org/10.1177/1069397117712194

http://hdl.handle.net/10138/225733

https://doi.org/10.1177/1069397117712194

other

acceptedVersion

Downloaded from Helda, University of Helsinki institutional repository.

This is an electronic reprint of the original article.

This reprint may differ from the original in pagination and typographic detail.

Please cite the original version. 


\section{City Research Online}

\section{City, University of London Institutional Repository}

Citation: Caprara, G. V., Vecchione, M., Schwartz, S. H., Schoen, H., Bain, P., Silvester, J., Cieciuch, J., Pavlopoulos, V. \& Bianchi, C. (2017). Basic values, ideological selfplacement, and voting: A cross-cultural study. Cross-Cultural Research, doi: $10.1177 / 1069397117712194$

This is the accepted version of the paper.

This version of the publication may differ from the final published version.

Permanent repository link: http://openaccess.city.ac.uk/16997/

Link to published version: http://dx.doi.org/10.1177/1069397117712194

Copyright and reuse: City Research Online aims to make research outputs of City, University of London available to a wider audience. Copyright and Moral Rights remain with the author(s) and/or copyright holders. URLs from City Research Online may be freely distributed and linked to.

City Research Online: $\quad$ http://openaccess.city.ac.uk/ $\quad$ publications@city.ac.uk




\title{
Basic values, ideological self-placement, and voting: A cross-cultural study
}

\author{
Gian Vittorio Caprara and Michele Vecchione \\ "Sapienza" University of Rome
}

Shalom H. Schwartz

The Hebrew University of Jerusalem

and the National Research University - Higher School of Economics

Harald Schoen

University of Bamberg, Germany

Paul G. Bain

University of Queensland, Australia

Jo Silvester

City University London, United Kingdom

Jan Cieciuch

University of Finance and Management, Warsaw, Poland

Vassilis Pavlopoulos

University of Athens, Greece

Gabriel Bianchi

Slovak Academy of Sciences, Slovak Republic

Maria Giovanna Caprara

Universidad a Distancia de Madrid, Spain

Hasan Kirmanoglu and Cem Baslevent

Istanbul Bilgi University, Turkey

Catalin Mamali

University of Wisconsin, Platteville, United States

Jorge Manzi

Pontificia Universidad Católica de Chile

Miyuki Katayama

Toyo University, Japan

Tetyana Posnova

Yuriy Fedkovich Chernivtsi national University, Ukraine

Carmen Tabernero

University of Cordoba, Spain

Claudio Torres

University of Brasilia, Brazil

Markku Verkasalo and Jan-Erik Lönnqvist

Institute of Behavioral Sciences, University of Helsinki, Finland

Eva Vondráková

Constantine the Philosopher University of Nitra, Slovak Republic 


\begin{abstract}
The current study examines the contribution of right-left (or conservative-liberal) ideology to voting, as well as the extent to which basic values account for ideological orientation. Analyses were conducted in 16 countries from 5 continents (Europe, North-America, South-America, Asia, and Oceania), most of which have been neglected by previous studies. Results showed that left-right (or liberal-conservative) ideology predicted voting in all countries except Ukraine. Basic values exerted a considerable effect in predicting ideology in most countries, especially in established democracies like Australia, Finland, Italy, UK, and Germany. Pattern of relations with the whole set of ten values revealed that the critical trade-off underlying ideology is between values concerned with tolerance and protection for the welfare of all people (universalism) versus values concerned with preserving the social order and status quo (security). A noteworthy exception was found in European post-communist countries, where relations of values with ideology were small (Poland) or near to zero (Ukraine, Slovakia).
\end{abstract}

Key-words: basic values; ideology; left-right; political orientation; voting 


\section{Basic values, ideological self-placement, and voting: A cross-cultural study}

The long-term decline of socio-structural factors as shapers of political preference has been a striking change for contemporary democracies (Jost, 2006; van der Brug 2010). The appeal of party identification has weakened (Dalton 2000). Social class, income, and education account for political preference less than in the past. Traditional ideological divisions between right and left (or conservative and liberal) appear less marked than in the past as political parties form coalitions and endorse political programs that are barely distinctive (Caprara, 2007). At the same time, ideological preferences are becoming more dependent upon voter's personality characteristics, such as traits (e.g., Gerber, Huber, Doherty, Dowling \& Ha, 2010; Jost, 2006; Schoen \& Schumann, 2007; Vecchione et al., 2011), and values (e.g., Barnea \& Schwartz, 1998; Caprara, Schwartz, Vecchione \& Barbaranelli, 2008; Thorisdottir, Jost, Liviatan \& Shrout, 2007; Vecchione, Caprara, Dentale \& Schwartz, 2013).

The above description applies to established Western democracies like United States, United Kingdom and Italy. One may wonder whether left-right and liberal-conservative ideological selfplacement hold the same meanings in re-established democracies, like Spain and Chile, and in postcommunist countries, where socialism has recalibrated the ideals of traditional left (Piurko, Schwartz \& Davidov, 2011). Likewise, one may wonder about the extent to which basic values operate as major organizers of ideological self-placement across different countries. The more one considers the diversity of people's living conditions, traditions, habits, ways of thinking and styles of relating to each other across the world, the more we are forced to revise the traditional western understanding of what really matters in political choices.

In this spirit, the present contribution aims to examine the extent to which left-right (or liberal-conservative) self-placement account for a major portion of voting behavior across 16 countries from 5 continents (Europe, North-America, South-America, Asia, and Oceania). Moreover, it examines the extent to which basic personal values account for ideological self- 
placement across countries that differ significantly in size, economics, religion, political history, and culture.

\section{Ideology}

In political science, ideology has been viewed as an interrelated set of attitudes and beliefs about the proper order of society and how it can be achieved (Erikson \& Tedin, 2003). Hence, ideology includes shared assumptions and beliefs about human nature and society and about ideals and priorities to be pursued. Different ideologies may contain competing views about how life should be lived and about how society should be governed. When shared by groups of individuals, these ideologies provide both an interpretation of the environment and a prescription for how the environment should be structured (Jost, Federico \& Napier, 2009). They can serve as organizing devices to structure political knowledge and expertise, or as broad postures that more or less consciously explain and justify different states of social and political affairs (Jost et al., 2009).

It is still a matter of debate whether a single right-left ideological dimension is sufficient to organize citizens' political knowledge and thought (e.g., Jost et al., 2009).

Since the time of the French revolution, ideological opinions have been classified most often in terms of a single right-left dimension. This dimension largely reflected the divide between preferences for stability (the status quo of the ancient regime) vs. change in early usage (Revelli, 2007). Much of the ideological conflict over change vs. status quo pertained to age-old disputes concerning the role of hierarchy, authority and tradition (Kitschelt, 2003). Over time and across countries, however, distinctions between right and left have changed. They have come to reflect a variety of combinations of ideals that pertain both to the private and public sphere of politics and to the social and economic spheres of life.

Currently, different conceptions of right and left apply in different polities. In established democracies like Australia, U.K., and U.S., right and left are often equated with conservative and liberal ideologies, respectively. The right is mostly associated with political movements that endorse traditional ideals like authority and social order, whereas the left is more often associated 
with political movements that endorse egalitarian ideals (Bobbio, 1996). Various forms of right and left, however, have also included movements that oppose authoritarian regimes and democracy and political programs that oppose free market economy and social welfare in various degrees (Giddens, 1994; Revelli, 2007). As Freeden (2010) noted, ideologies shade off into each other and cut through one another. Although most modern democracies have become more egalitarian in terms of civil rights and access to health services, education and work opportunities, achieving the optimal combination of individual freedom and social justice is an arduous challenge for the left and right in most countries. Thus it is sometimes difficult to discern what is common among parties and movements that claim to endorse the same ideology.

Several researchers still wonder whether one dimension is sufficient to illuminate the structure of political choices (e.g., Ashton et al., 2005; Heath, Evans, \& Martin, 1994; Ricolfi, 2002). Others have suggested decomposing the left-right distinction into economic and social dimensions (Feldman \& Johnston, 2014). Conceptions of freedom in politics and in economics are in fact difficult to reconcile under one left-right dimension in modern democracies. The left is often been identified with political programs that limit individuals' economic freedom but advocate maximum freedom in the sphere of civil rights. The right is often identified with political programs that curtail citizens' freedom in the sphere of civil rights but advocate maximum freedom in the sphere of economics.

Nonetheless, the left-right and liberal-conservative distinctions have survived over the centuries to map a political space made of ideas and people that occupy opposing positions. These distinctions still hold even where opposing political coalitions have adopted more pragmatic platforms intended to attract a wide swath of the electorate, platforms that are much less distinctive. Likely, the more party coalitions lead to bipolar polities and pose a choice between two major options, the more the traditional ideological divide can serve as a knowledge and communication device that helps citizens to orient themselves in a complex political universe. 
Moreover, one should consider that self-placing on the left-right or liberal-conservative continuum may have an affective value in itself, as it enables people to make choices that accord with their basic dispositions and to sort the political world into "us" and "them" (Jacoby, 2009; Sears \& Funk, 1999). Self identifying along a unique ideological dimension may satisfy people's needs of social inclusion and belonging, despite the diversity of contents that can be traced to the opposite poles of that dimension across polities (Nozick, 1989).

Based on this reasoning, we posited that the single ideological dimension continues to be an important organizer of political thought. We expected that left-right and conservative-liberal ideologies are major predictors of political choices across democracies that differ widely in their history and degree of establishment.

\section{Basic Values}

A number of scholars have assigned a central role to values as organizers of political preferences and judgments (Knutsen, 1995; Rokeach, 1973, 1979; Schwartz, 1994; Schwartz, Caprara \& Vecchione, 2010). Values are cognitive representations of desirable, abstract, transsituational goals that serve as guiding principles in people's lives. They refer to what people consider important, and vary in their relative importance as standards for judging behavior, events, and people (Schwartz, 1992).

Although the relationship between values and political orientation has been addressed from different perspectives (Braithwaite, 1997; Knutsen, 1995; Rokeach, 1973), most recent studies adopt Schwartz's ten basic personal values (Schwartz, 1992, 1994). This theory proposes ten broad, motivationally distinct values derived from universal requirements of the human condition: Security, power, achievement, hedonism, stimulation, self-direction, universalism, benevolence, tradition, and conformity. The type of goal or motivation a value expresses distinguishes one value from another. As shown in Figure 1, the ten values can be located around a motivational circle. Within this circular structure, values that are adjacent (e.g., benevolence and universalism) share similar motivational emphases and are positively related. By contrast, values located on opposite sides of 
the circle (e.g. power and universalism) express conflicting motives and are negatively related (Schwartz, 1992, 2005). This structure implies that adjacent values have similar correlations with other variables. These correlations should decline in both directions, reaching the most negative value in correspondence of opposing values in the circle (see Schwartz, 2006).

Based on this pattern of conflicts and compatibilities, the ten values can be grouped under four broader dimensions: (1) values that emphasize self-enhancement (power and achievement); (2) values that emphasize transcending personal interests and promoting the welfare of others (universalism and benevolence); (3) values that emphasize conservation of the status quo (security, tradition, and conformity); (4) values that emphasize openness to change (self-direction, stimulation, and hedonism).

Using the Schwartz's taxonomy, several studies have shown that citizens tend to vote for parties or coalitions whose policies they perceive as likely to promote or protect their important values. A study of the 1988 Israeli elections showed that basic values discriminated significantly between voters of different political parties (Barnea \& Schwartz, 1998). In Italy, voters for the centre-right coalition gave higher priority to the self-enhancement and conservation values, whereas voters for the centre-left coalition gave higher priority to the self-transcendence values (e.g., Caprara, Schwartz, Capanna, Vecchione \& Barbaranelli, 2006; Schwartz et al., 2010).

Other studies have focused on the relation between values and ideological self-placement. Using data from the ESS third (2006-2007) round of the European Social Survey (ESS), Piurko et al. (2011) found that self-enhancement and conservation values explained a right orientation, whereas self-transcendence and openness to change values explained a left orientation. They also found that values had greater explanatory power in countries with a long tradition of liberal democracy, like Germany and the UK, than in post-communist countries.

Aspelund et al. (2013) analyzed data from 28 European countries using data from the third (2006-2007) and fourth (2008-2009) rounds of the ESS. They found that conservation vs. openness to change was significantly related to right-wing orientation in almost all Western countries. 
Relationships in Central and Eastern European countries, by contrast, were much less consistent. Self-enhancement vs. self-transcendence was significantly related to right-wing orientation in the vast majority of Western European countries, although more weakly than conservation values. Few correlations were found to be significant among Central and Eastern European countries.

\section{The present research}

The current study examines the extent to which personal values account for left-right (or liberal-conservative) ideological self-placement in 16 countries from 5 continents (Europe, NorthAmerica, South-America, Asia, and Oceania). It extends prior research on links between values and ideology in Europe (Aspelund et al., 2013; Piurko et al., 2011; Thorisdottir et al., 2007) by considering non-European countries that previous works have often neglected. We include established democracies (Australia, Finland, Germany, Israel, Italy, Japan, United Kingdom, and the United States), countries in which democracy has been re-established after a more or less prolonged interval of authoritarian regimes (Brazil, Chile, Greece, Spain, Turkey), and postcommunist countries (Poland, Slovakia, and Ukraine).

Moreover, the present study measures values with the full 40-item PVQ, which allows assessing the ten basic personal values with adequate reliability, and examining their relations with ideological self-placement. It complements and extends earlier cross-cultural studies, which relied on the PVQ-21.

We examined the pattern of relations of the whole set of values with ideological selfplacement. Right and conservative ideologies of most countries emphasize security, limited government, and traditional family and national values. Such policy is compatible with and may express the motivational goals of security and tradition values. Left and liberal ideologies, in contrast, emphasize the merits of the welfare state, express strong concern for social justice, tolerance of diverse groups (even those that might disturb the conventional social order), and emphasize pluralism and equality (Bobbio, 1996). The expected consequences of such a policy are compatible with universalism values. 
We therefore expect that ideological self-placement on the left/right and the liberalconservative scales correlate most positively with universalism values and most negatively with security and tradition values. The circular motivational structure of the ten values implies that correlations would decline from universalism to security and tradition in both directions around the circle.

While this is the expected pattern, a certain degree of variability in the strength of the relationships is to be expected. As argued by Barnea and Schwartz (1998) the predictive validity of particular values may vary as a function of the ideological content of the political discourse. Moreover, in keeping with previous results (Aspelund et al, 2013; Piurko et al., 2011), we expect that the contribution of basic values to ideological self-placement is stronger in established democracies than in post-communist societies.

\section{Methods}

\section{Participants and Procedures}

This study involved 16 countries. Data from 15 countries (Australia, Brazil, Chile, Finland, Germany, Greece, Israel, Italy, Poland, Slovakia, Spain, Turkey, Ukraine, the United Kingdom, the United States) were available from a cross-cultural project aimed at investigating the role of values in shaping political preferences (Schwartz et al., 2013; Vecchione et al., 2015). We performed secondary analysis of data in these countries. Additional data have been collected in Japan. This allowed us to extend the generalizability of results to an Asiatic country.

As described in Schwartz et al. (2013), a representative national sample was obtained in Germany and Turkey. Researchers from other countries enlisted university students to gather the data. The same instructions for administering the instruments were used in all countries. Table 1 presents the characteristics of the samples.

\section{Measures}

Ideology. Ideology was measured in each country through two distinct indicators. The first was a self-placement item on the liberal-conservative scale: "In political matters, people sometimes 
talk about conservatives and liberals. How would you place your views on this scale, generally speaking?". Alternatives ranged from 1 (Extremely liberal) to 7 (Extremely conservative). The second was a self-placement item on the left-right scale: 'In political matters, people sometimes talk about and "the left" and "the right" How would you place your views on this scale, generally speaking?" Alternatives ranged from 1 (Left) to 10 (Right). We used the liberal-conservative scale in the U.K. and the U.S., and the left-right scale in all other countries. This decision was based on input from the country collaborators about the common usage in their country. The left-right item was rescaled to a 7-point scale, have the same range of the liberal-conservative scale.

Voting. We measured political choice directly by asking participants which party they had voted for in the most recent national election. We included parties with at least 25 voters in the analysis. To maximize the number of cases in the analysis, researchers in nine out of sixteen countries combined small parties $(n<25)$ with larger parties or with one another, based on the similarity of their ideological orientations. Voting was coded as an ordered categorical variable, by positioning political parties along the left-right continuum. The number of categories varied across nations, from two (U.S.) to six (Israel), depending on the number of political parties that were considered.

Values. The PVQ (Schwartz, 2005) measured basic values. It includes 40 short verbal portraits of different people matched to the respondents' gender, each describing a person's goals, aspirations, or wishes that point implicitly to the importance of a value. For example, "Thinking up new ideas and being creative is important to him. He likes to do things in his own original way" describes a person who holds self-direction values important. Three to six items measure each value. For each portrait, respondents indicate how similar the person is to themselves on a scale ranging from "not like me at all" to "very much like me." We infer respondents' own values from the implicit values of the people they consider similar to themselves. In the current study, Cronbach's alpha reliabilities averaged across the sixteen samples ranged from .62 (Tradition) to .89 (Universalism). 


\section{Results}

\section{Ideological self-placement and voting}

The left panel of Table 2 reports country means and standard deviations for the left-right and the liberal-conservative scales. Participants with missing data on ideological self-placement $(3.6 \%$ of the total sample) were excluded from the analysis. ${ }^{1}$ The mean of left-right ideology ranged across countries from 3.38 (Australia) to 6.23 (Poland). The mean score of liberal-conservative selfplacement was 3.12 in the UK, and 3.90 in the US. The right panel of Table 2 reports Spearman's correlations of ideological self-placement with voting. Correlations were significant in all countries except Ukraine. The preference for a left-wing (or liberal) ideology was consistently associated with voting for left-wing parties. According to Cohen's (1988) standards, correlations were large in Australia, Brazil, Finland, Germany, Greece, Israel, Italy, Spain, Turkey, and the United States, moderate in Chile, Poland, Slovakia, and United Kingdom, and small in Japan.

\section{The contribution of basic values to ideological self-placement}

We used a multilevel regression analysis to investigate the unique contribution of the ten values to ideology in the overall sample, controlling for basic socio-demographic variables (gender, age, income, and education). This approach, often referred to as random coefficient model (Kreft \& De Leeuw, 1998), takes into account the nested nature of the data (individuals are nested within countries). It permits examining the effect of individual-level variables on ideological selfplacement, without incurring problems typically associated with the use of ordinary least squares regression with nested data. It also allows examining whether these effects vary significantly across countries.

In a first step we estimated an empty model, which only includes the intercept. This model was estimated to calculate the Intraclass Correlation Coefficient (ICC) of ideological self-placement.

\footnotetext{
${ }^{1}$ The percentage of missing cases for each country were: $0.0 \%$ in Australia, $1.7 \%$ in Brazil, $3.6 \%$ in Chile, $2.0 \%$ in Finland, $8.8 \%$ in Germany, $1.1 \%$ in Greece, $1.7 \%$ in Israel, $4.8 \%$ in Italy, $8.5 \%$ in Japan, $3.1 \%$ in Poland, 2.1\% in Slovakia, 2.1\% in Spain, 6.0\% in Turkey, 0.0\% in Ukraine, $0.0 \%$ in the United Kingdom, and $6.4 \%$ in the United States.
} 
The ICC was .08 , indicating that $8 \%$ of the total variance in ideology was accounted for by differences between countries.

We then estimated a random-intercept model, which adds level-1 explanatory variables (i.e., basic personal values and socio-demographic variables). We centered the ten values and the continuous demographic variables on their group mean. Gender was coded as 0 (female) and 1 (male). Results showed that the three conservation values (security, $b=.16, \mathrm{p}<.001$, tradition $b$ $=.10, \mathrm{p}<.001$, and conformity $b=.10, \mathrm{p}<.001)$, predicted a preference for right/conservative ideology (a higher score on the scale). Power $(b=.05, \mathrm{p}<.01)$ and stimulation $(b=.05, \mathrm{p}<.01)$ were also related to a preference for right/conservative ideology, although to a lesser extent. Universalism $(b=-.31, \mathrm{p}<.001)$ and hedonism $(b=-.07, \mathrm{p}<.01)$ predicted a preference for left/liberal ideology (a lower score on the scale). Among the demographics, education $(b=-.01$, p. $<05)$, and income $(b=-.06, \mathrm{p}<.01)$ predicted a preference for left/liberal ideology.

Figure 2 reports full set of unstandardized regression coefficients for personal values. As can be observed, the coefficients followed the motivational circle of values, declining from security to universalism in both directions. All these relationships, except for in the case of universalism, were quite weak. This figure, however, reflects the overall effects on ideology across the sixteen samples. Allowing the relationship between ideology and values to vary across countries we found that the effects of five values (conformity, security, tradition, universalism, and power) varied significantly ( $\mathrm{p}<.01)$. This suggests that the same pattern cannot be generalized to all countries. We therefore performed separate analyses for each sample, using OLS multiple regression.

Table 3 presents the unique contribution of values to ideological self-placement in each country, controlling for the effect of the demographic variables. Given the high number of tests being performed, we applied a Bonferroni correction to determine whether each of the ten regression coefficient was significant in each country (i.e., the critical level of significance was set at .01). We found that universalism values predicted a preference for left/liberal ideology in all countries, except Ukraine and Slovakia. Security, tradition, and conformity values predicted a 
preference for right/conservative ideology in most countries. The effects of the other values were weaker and much less consistent across countries.

To evaluate the degree of deviation from the overall pattern, we calculated the Pearson's correlation between the ten regression coefficients derived from aggregated data and the regression coefficients estimated in each country. ${ }^{2}$ Pearson's $r$ was higher than $.80(p<.05)$ in 13 of 16 countries, revealing a substantial homogeneity in the effect that values exerted on ideology (Table 3, last column). In the post-communist countries, by contrast, Pearson's r was considerably lower and not significant. ${ }^{3}$

The incremental contribution of basic values, after controlling for the effect of the demographics, was substantial in most samples. In Western and Southern European countries, the R-squared ranged from .18 (Germany) to .32 (Finland). A similar effect was found in non-European countries, where the R-squared varied between .12 (Japan) and .26 (Australia). The smallest contribution was observed in the three Post-communist countries, where the R-squared ranged from .05 (Slovakia) to .09 (Poland).

\section{Discussion}

The aim of this study was to examine the association between ideological self-placement and voting, as well as pattern of relations between Schwartz's basic personal values and ideological self-placement across 16 countries that differ widely in their traditions, cultural and historical roots. Ideology is the strongest predictor of voting in all countries, except for Ukraine. The highest correlations (.70 or higher) were observed in Chile, East Germany, Israel, Italy, and Spain, where ideological self-placement serves as a virtual proxy for voting choice. This pattern of results suggests that claims of the end of ideology and the decline of the right and left divide have been prematurely announced, as already noted by Jost (2006). Although the underlying principles are

\footnotetext{
${ }^{2}$ To avoid inflated coefficients, Pearson's correlations for each country were based on aggregate data from which the examined country was excluded. We thank an anonymous reviewer for suggesting this procedure. ${ }^{3}$ Preliminary analysis showed that multicollinearity diagnostics were in the acceptable range (VIF values were higher than .8 in each country, which is far above the acceptable limit of .1, see Cohen, Cohen \& Aiken, 2003).
} 
complex and difficult to grasp, the traditional left-right distinction still serves as useful heuristic device that helps voters to organize political knowledge, to assess political programs, to structure their judgments and to make their choices (Sears, Lau, Tyler, \& Allen, 1980). Likely right and left are ideological labels that have an intrinsic value, even if they do not always share the same meanings and carry the same priorities across different polities. Yet, they may act as attractors that, at collective level, enable people to take position with others and to strengthen consensus.

This occurs in established democracies where citizens are accustomed to voting as an act that is both symbolic and expressive and that goes beyond contingent interests. People vote despite being aware their single vote is almost irrelevant with respect to the final outcome of an election. People vote regardless of their position in society as voting attest to the personal and social identity they cherish, to their being persons worthy of respect, to the equal dignity of their views as citizens, and to their belongingness and inclusiveness (Caprara, 2008). In this regard, ideology is the device that allows people to cope with complexity and that meet the two fundamental needs of human existence, agency and communion, namely the needs to exert one's own will and to feel part of a community.

The power of ideology in accounting for voting holds also in post-communist societies, like Poland and Slovakia, although to a lesser extent. In these countries, the demise of socialist ideals has carried tremendous changes in the political landscape. Ukraine constituted the only country that showed no relation between ideology and voting. One may speculate about the different historical vicissitudes and political traditions of this country, which may account for its being an outlier, even with regard to Poland and Slovakia.

The pattern of relationship of ideological self-placement with basic values revealed that the critical trade-off underlying ideology is between values concerned with tolerance and protection for the welfare of all people (universalism) versus values concerned with preserving the social order and status quo (security).

Universalism and security are located on opposite sides of the motivational circle of values 
(Schwartz, 1992), as they express conflicting motivations, that seems to correspond closely to liberalism and social welfare vs. social conservatism. Universalism values call for promoting the welfare of others even at cost to the self. Moreover, they express concern for the weak, those most likely to suffer from market-driven policies. Security values emphasize preserving the social order. The trade-off between these two values seems to capture particularly well the ideological divide in most countries (e.g., Braithwaite, 1997; Jost, Glaser, Kruglanski \& Sulloway, 2003).

It is remarkable that similar results hold across countries, despite the different trajectories to democracy and the diversities of contents that can be traced under the same ideological labels. A notable exception was found in post-communist countries, especially in Ukraine and Slovakia, where relations of values with ideology were near to zero. In this regard, one may speculate about the different historical vicissitudes and political traditions of these countries, even with regard to other post-communist countries, like Poland. It is possible that the experience of communism in these countries has erased memories of past democratic regimes, and that the profound changes following its collapse resulted in confusion about the definition of left and right. Future studies should further investigate the extent to which past and contingent ideological forces impinge on voting among post-communist countries whose transition to democratic institutions is still far from being fully achieved.

When interpreting the results of this study, potential limitations should be considered, attributable to sampling or methodological artifacts. A first limitation is that participants were from convenience samples, except for in Germany and Turkey. Thus one can't generalize our findings to the entire countries population. For example, participants included in our samples of convenience were more educated, wealthier, and urban than the general population. Yet, the patterns of findings in national samples were largely consistent with those from samples of convenience. Moreover, we cannot exclude that differences across countries in the strength of the effects was due, at least in part, by differences in the reliability of the measures. A further limitation is the limited number of countries, which did not allow us to investigate the role of cultural level variables in moderating the 
strength of the relations between values and ideology. Future studies, using a higher number of representative samples from over the world, are needed to investigate the role of different countrylevel variables, such as economic development of the country, level of democratization, type and importance of religion (for a similar approach, see for instance, Bond et al., 2004).

Despite the above limitations, we believe that this study is informative regarding the relationship among basic values, ideological orientation, and voting in a variety of representative democracies. The relatively consistent pattern of covariation between these variables suggests that political ideology has a common core of meaning, despite the diversity of left/liberal and right/conservative policies across countries. 


\section{References}

Ashton, M.C., Danso, H.A., Maio, G.R., Esses, V.M., Bond, M.H., Keung, D.K.Y. (2005). Two dimensions of political attitudes and their individual difference correlates: A cross-cultural perspective. In R.M. Sorrentino, D. Cohen, J.M. Olsen, \& M.P. Zanna (Eds.), Culture and social behavior (pp. 1-29). New Jersey: Lawrence Erlbaum Associates.

Aspelund, A., Lindeman, M., \& Verkasalo, M. (2013). Political conservatism and left-right orientation in 28 eastern and western European countries. Political Psychology, 34, 409-417.

Barnea, M., \& Schwartz, S.H. (1998). Values and voting. Political Psychology, 19, 17-40.

Bobbio, N. (1996). Left and right: The significance of a political distinction. Cambridge, UK: Polity Press.

Bond, M. H., Leung, K., Au, A., Tong, K. K., de Carrasquel, S. R., Murakami, F., et al. (2004). Culture-level dimensions of social axioms and their correlates across 41 cultures. Journal of Cross-Cultural Psychology, 35, 548-570

Braithwaite, V.A. (1997). Harmony and security value orientations in political evaluation. Personality and Social Psychology Bulletin, 23, 401-414.

Caprara, G.V. (2007). The personalization of modern politics. European Review, 15, 151-164.

Caprara, G.V. (2008). Will democracy win? Journal of Social Issues, 64, 639-659.

Caprara, G.V., Schwartz, S.H., Capanna, C., Vecchione, M., \& Barbaranelli, C. (2006). Personality and politics: Values, traits, and political choice. Political Psychology, 27, 1-28.

Caprara, G.V., Schwartz, S.H., Vecchione, M., Barbaranelli, C. (2008). The personalization of politics: Lessons from the Italian case. European Psychologist., 13, 157-172.

Cohen, J. (1988). Statistical power analysis for the behavioral sciences (2nd ed.). Hillsdale, NJ: Lawrence Earlbaum Associates.

Cohen, J., Cohen, P., West, S.G., \& Aiken, L.S. (2003). Applied multiple regression/correlation analysis in the behavioral sciences. Mahwah, NJ: Erlbaum. 
Converse, P.E. (1964). The nature of belief systems in mass publics. In D.E. Apter (Ed.), Ideology and discontent (pp. 206-261). New York: Free Press.

Dalton, R.J. (2000). The decline of party identification. In R.J. Dalton and M.P. Wattenberg (Eds.) Parties without partisans (pp. 19-36). Oxford: Oxford University Press.

Erikson, R.S., \& Tedin, K.L. (2003). American Public Opinion. New York: Longman. 6th ed.

Feldman, S., \& Johnston, C. (2014). Understanding the determinant of political ideology:

Implications of structural complexity. Political Psychology, in press.

Freeden, M. (2010). Ideology: A very short introduction. Oxford University Press.

Gerber, A.S, Huber, G., Doherty, D., Dowling, C., \& Ha, S. (2010). Personality and political attitudes: Relationships across issue domains and political contexts. American Political Science Review, 104, 111-133.

Giddens, A. (1994). Beyond left and right: The future of radical politics. Cambridge: Polity Press.

Heath, A., Evans, G., \& Martin, J. (1994). The measurement of core beliefs and values: The development of balanced socialist/laissez faire and libertarian/authoritarian scales. British Journal of Political Science, 24, 115-133.

Jacoby, W.G. (2009). Ideology and vote choice in the 2004 election. Electoral Studies, 28, 584-594.

Jost, J.T. (2006). The end of the end of ideology. American Psychologist, 61, 651-670.

Jost, J.T., Federico, C.M., \& Napier, J.L. (2009). Political ideology: Its structure, functions, and elective affinities. Annual Review of Psychology, 60, 307-337.

Jost, J.T., Glaser, J., Kruglanski, A.W., \& Sulloway, F.J. (2003). Political conservatism as motivated social cognition. Psychological Bulletin, 129, 339-375.

Kitschelt, H, (2003). Diversification and Reconfiguration of Party Systems in Postindustrial Democracies, Friedrich-Ebert-Stiftung, Bonn.

Knutsen, O. (1995). Party choice. In J.W. van Deth \& E. Scarbrough (Eds.), The impact of values. New York: Oxford University Press.

Kreft, I., \& De Leeuw, J. (1998). Introducing multilevel modeling. London: Sage Publications. 
Nozick, R. (1989). The examined life: Philosophical meditations. New York: Simon \& Schuster.

Piurko, Y., Schwartz, S.H., Davidov, E. (2011). Basic personal values and the meaning of left-right political orientations in 20 countries. Political Psychology, 32, 537-561.

Revelli, M. (2007). Sinistra Destra. L'identità smarrita. Bari, Laterza.

Ricolfi, L. (2002). La frattura Etica. La ragionevole sconfitta della sinistra [The ethical rift. The reasonable defeat of the left]. Naples, Italy: L'Ancora del Mediterraneo.

Rokeach, M. (1973). The nature of human values. New York: Free Press.

Rokeach, M. (1979). The two-value model of political ideology and British politics. British Journal of Social and Clinical Psychology, 18, 169-172.

Schoen, H., \& Schumann, S. (2007). Personality traits, partisan attitudes, and voting behavior. Evidence from Germany. Political Psychology, 28, 471-498.

Schwartz, S.H. (1992). Universals in the content and structure of values: Theoretical advances and empirical tests in 20 countries. In M.P. Zanna (Ed.), Advances in Experimental Social Psychology, 25 (pp. 1-65). New York: Academic Press.

Schwartz, S.H. (1994). Are there universal aspects in the structure and contents of human values? Journal of Social Issues, 50, 19-45.

Schwartz, S.H. (2005). Robustness and fruitfulness of a Theory of Universals in Individual Values. In A. Tamayo \& Porto (Eds.), valores e trabalho [Values and work]. Brasilia: Editora Universidade de Brasilia.

Schwartz, S.H. (2006). Les valeurs de base de la personne: Théorie, mesures et applications [Basic human values: Theory, measurement, and applications]. Revue Francaise de Sociologie, 42, 249-288.

Schwartz, S.H., Caprara, G.V., \& Vecchione, M. (2010). Basic personal values, core political values and voting: A longitudinal analysis. Political Psychology, 31, 421-452. 
Schwartz, S.H., Caprara, G.V., Vecchione, M., Bain, P., Baslevent, C., Bianchi, G., ... \& Verkasalo, M. (2013). Basic personal values constrain and give coherence to political values: A cross national study in 15 countries. Political Behavior, 36, 899-930.

Sears, D.O., \& Funk, C.L. (1999). Evidence of the long-term persistence of adults' political predispositions. Journal of Politics, 61, 1-28.

Sears, D.O., Lau, R.R., Tyler, T.R., \& Allen, H.M. (1980). Self-interest vs. symbolic politics in policy attitudes and presidential voting. American Political Science Review, 74, 670-684.

Thorisdottir, H., Jost, J.T., Liviatan, I., \& Shrout, P.E. (2007). Psychological needs and values underlying the left-right political orientation: Cross-national evidence from Eastern and Western Europe. Public Opinion Quarterly, 71, 175-203.

Van der Brug, W. (2010). Structural and ideological voting in age cohorts. West European Politics, $33,586-607$.

Vecchione, M., Caprara, G.V., Dentale, F., \& Schwartz, S.H. (2013). Voting and values: Reciprocal effects over time. Political Psychology, 34, 465-485.

Vecchione, M., Schoen, H., González Castro, J.L., Cieciuch, J., Pavlopoulos, V., \& Caprara, G.V. (2011). Personality correlates of party preference: the Big Five in five big European countries. Personality and Individual Differences, 51, 737-742.

Vecchione, M., Schwartz, S.H., Caprara, G.V., Schoen, H., Cieciuch, J., Silvester, J., ... \& Alessandri, G. (2015). Personal values and political activism: A cross-national study. British Journal of Psychology, 106, 84-106. 
Table 1. Description of the samples.

\begin{tabular}{|c|c|c|c|c|c|}
\hline Country & $\mathrm{N}$ & $\%$ Female & $\begin{array}{c}\text { Mean age } \\
\text { (SD) }\end{array}$ & $\begin{array}{l}\text { Mean years of } \\
\text { education }(\mathrm{SD})^{\mathrm{a}}\end{array}$ & $\begin{array}{l}\text { Median household } \\
\text { income }^{\mathrm{b}}\end{array}$ \\
\hline Australia & 285 & $54 \%$ & $36.1(13.9)$ & $16.6(3.6)$ & 3 \\
\hline Brazil & 995 & $56 \%$ & $34.1(9.0)$ & $19.1(4.1)$ & 2 \\
\hline Chile & 415 & $50 \%$ & $43.3(13.4)$ & $15.8(4.2)$ & 3 \\
\hline Finland & 428 & $68 \%$ & $40.1(13.2)$ & $16.2(4.3)$ & 4 \\
\hline Germany & 1066 & $46 \%$ & $53.7(16.4)$ & $14.6(4.4)$ & 4 \\
\hline Greece & 374 & $48 \%$ & $41.9(12.0)$ & $15.3(3.5)$ & 3 \\
\hline Israel & 478 & $57 \%$ & 38.6 (12.7) & $15.6(3.0)$ & 4 \\
\hline Italy & 557 & $56 \%$ & 38.7 (13.9) & $15.3(3.7)$ & 4 \\
\hline Japan & 364 & $54 \%$ & $44.6(13.9)$ & $14.5(2.5)$ & 3 \\
\hline Poland & 699 & $56 \%$ & $36.6(13.0)$ & $15.1(3.0)$ & 4 \\
\hline Slovakia & 485 & $51 \%$ & $47.7(14.6)$ & $14.4(3.3)$ & 5 \\
\hline Spain & 420 & $54 \%$ & 37.7 (14.8) & $14.3(3.1)$ & 4 \\
\hline Turkey & 512 & $46 \%$ & 37.7 (13.2) & $11.4(3.3)$ & 5 \\
\hline Ukraine & 735 & $48 \%$ & $41.1(12.6)$ & $14.0(3.3)$ & 4 \\
\hline United Kingdom & 469 & $64 \%$ & $36.7(12.1)$ & $14.2(2.9)$ & 2 \\
\hline United States & 543 & $56 \%$ & $32.6(14.4)$ & $14.0(2.2)$ & 4 \\
\hline
\end{tabular}

Notes. ${ }^{\mathrm{a}}$ Include compulsory years of schooling; ${ }^{\mathrm{b}}$ Income was measured with the following scale: $1=$ very much above the average of your country, $2=$ above the average, $3=a$ little above average, $4=$ about average, $5=$ a little below the average, $6=$ below the average, $7=$ very much below the average. 
Table 3. Standardized OLS regression coefficients relating basic values to ideological self-placement.

\begin{tabular}{|c|c|c|c|c|c|c|c|c|c|c|c|c|}
\hline & $\overline{\mathrm{SE}}$ & $\mathrm{CO}$ & TR & $\mathrm{BE}$ & UN & SD & ST & $\mathrm{HE}$ & $\mathrm{AC}$ & PO & $\mathrm{R}^{2}$ & $\begin{array}{l}\text { Similarity with } \\
\text { the overall pattern }\end{array}$ \\
\hline Australia & $.23 * *$ & .07 & .14 & .03 & $-.24 * *$ & -.10 & .16 & -.15 & -.01 & $.18^{*}$ & .26 & $.86^{* *}$ \\
\hline Brazil & $.16^{* *}$ & $.12 * *$ & $.12 * *$ & .04 & $-.32 * *$ & -.03 & .02 & -.09 & .05 & $.10 *$ & .17 & $.93 * *$ \\
\hline Chile & .14 & $.22 * *$ & .00 & .06 & $-.30 * *$ & .07 & .02 & .03 & -.07 & .09 & .20 & $.71 * *$ \\
\hline Finland & $.25^{* *}$ & $.19^{* *}$ & .02 & .06 & $-.41 * *$ & .02 & $.15^{* *}$ & -.09 & .02 & .06 & .32 & $.84 * *$ \\
\hline Germany & $.24 * *$ & .04 & $.25^{* *}$ & -.05 & $-.32 * *$ & .07 & .07 & -.06 & -.09 & .03 & .18 & $.95 * *$ \\
\hline Greece & $.20 * *$ & -.05 & $.31 * *$ & -.02 & $-.37 * *$ & .06 & .00 & .05 & .08 & .02 & .29 & $.86^{* *}$ \\
\hline Israel & $.22 * *$ & -.02 & $.42 * *$ & -.01 & $-.31 * *$ & .05 & .11 & -.03 & -.04 & .03 & .31 & $.90 * *$ \\
\hline Italy & $.23^{* *}$ & .07 & $.14^{* *}$ & .05 & $-.38 * *$ & .04 & -.09 & .00 & .11 & .10 & .27 & $.83 * *$ \\
\hline Japan & $.24 * *$ & .04 & $.19 * *$ & .00 & $-.24 * *$ & -.11 & .10 & -.10 & .00 & .05 & .12 & $.92 * *$ \\
\hline Poland & $.12 *$ & -.09 & $.24 * *$ & .02 & $-.15^{*}$ & .13 & .02 & -.09 & -.01 & -.13 & .09 & $.62 *$ \\
\hline Slovakia & -.10 & -.09 & .04 & .09 & -.01 & -.03 & .03 & -.11 & -.04 & .06 & .05 & .04 \\
\hline Spain & .05 & $.18^{*}$ & .15 & .09 & $-.32 * *$ & -.10 & .12 & -.01 & -.10 & .11 & .22 & $.83^{* *}$ \\
\hline Turkey & .12 & .00 & $.19^{* *}$ & -.03 & $-.17 * *$ & -.11 & .02 & -.06 & -.07 & .07 & .13 & $.88 * *$ \\
\hline U.K. & $.23^{* *}$ & .03 & $.24 * *$ & -.03 & $-.35^{* *}$ & -.08 & .06 & -.06 & .01 & .09 & .30 & $.98 * *$ \\
\hline Ukraine & .01 & .04 & $.10^{*}$ & $-.11 *$ & .01 & .08 & $.17 * *$ & -.03 & -.03 & -.03 & .06 & .24 \\
\hline U.S. & .03 & .14 & $.22 * *$ & .08 & $-.29 * *$ & -.06 & .10 & -.03 & -.01 & .02 & .16 & $.88^{* *}$ \\
\hline
\end{tabular}

Notes. ${ }^{*} p<.01 ; * * p<.001 ; \mathrm{SE}=$ Security; $\mathrm{CO}=$ Conformity; $\mathrm{TR}=$ Tradition; $\mathrm{BE}=$ Benevolence; UN = Universalism; $\mathrm{SD}=$

Self-direction; ST = Stimulation; $\mathrm{HE}=$ Hedonism; $\mathrm{AC}=$ Achievement; $\mathrm{PO}=$ Power . 


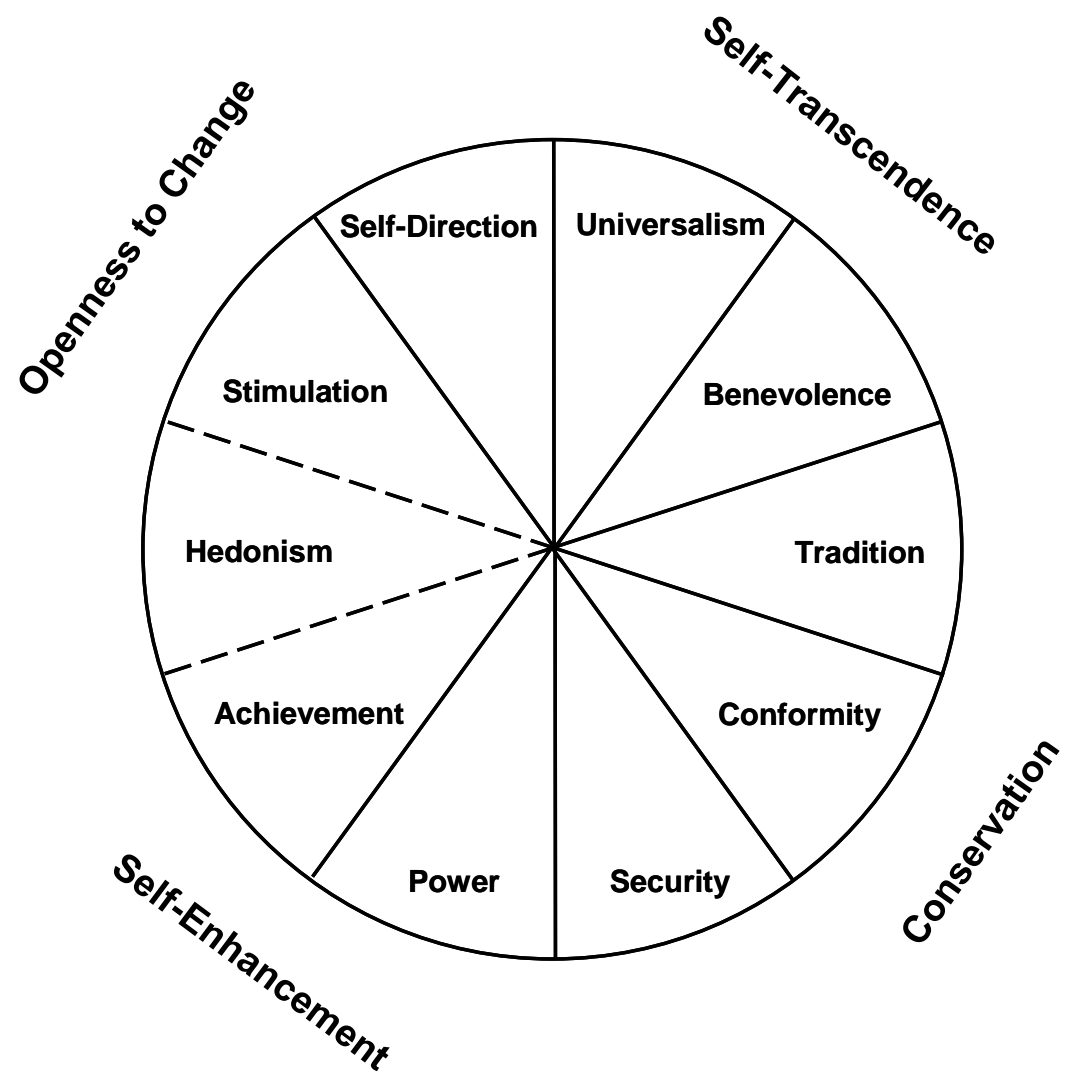

Figure 1. Schwartz's (1992) circular model of values. 


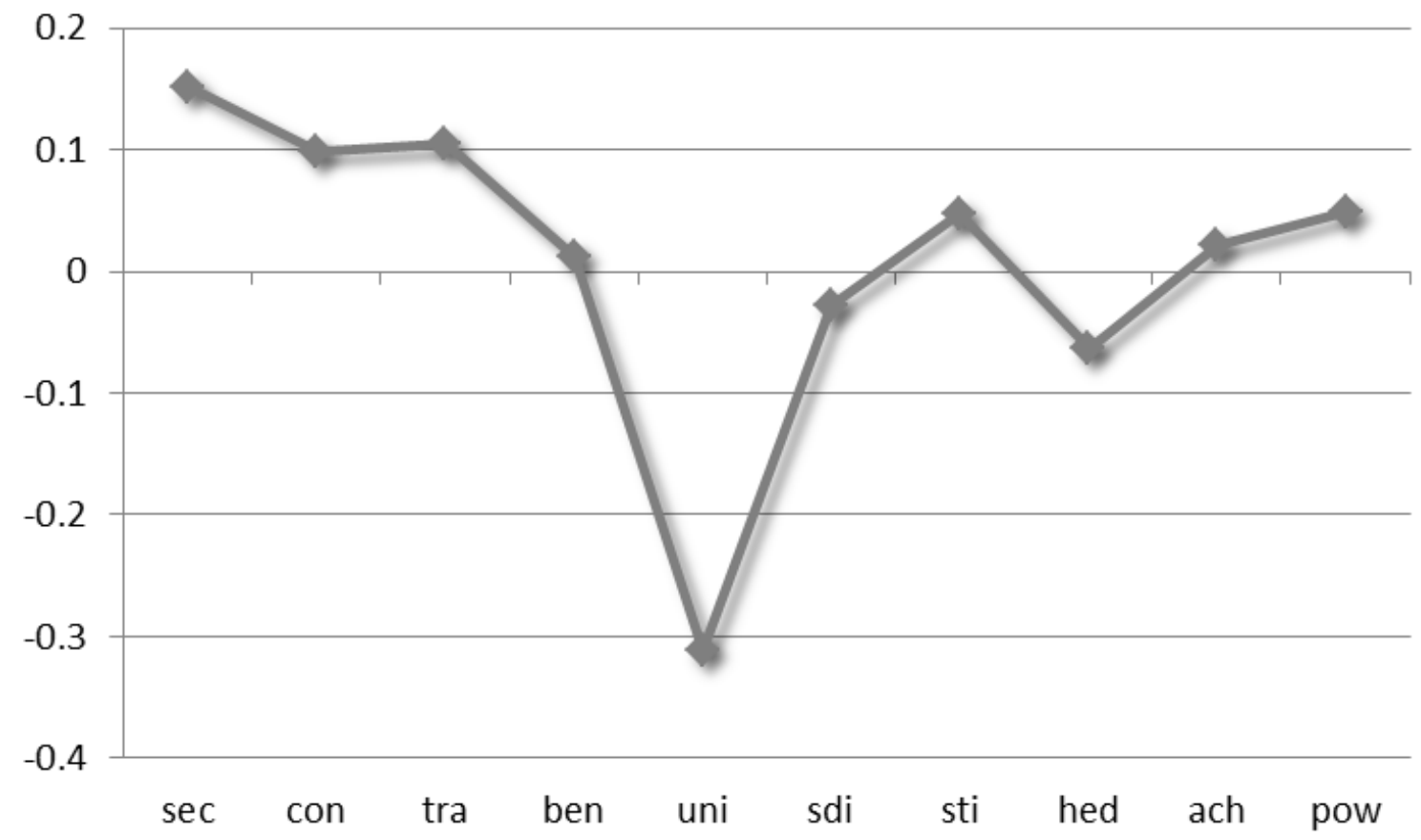

Figure 2. Unstandardized regression coefficients relating basic values to ideology in a multilevel analysis (positive coefficients signify that a value is related to a preference for a right/conservative ideology, and vice versa).

Sec $=$ security $;$ con $=$ conformity $;$ tra $=$ tradition $;$ ben $=$ benevolence $;$ uni $=$ universalis $m ;$ sdi $=$ self-direction; sti = stimulation; hed = hedonism; ach = achievement; pow = power 
Appendix. Political parties, ordered from left to right, and number of voters for each.

\begin{tabular}{|c|c|c|}
\hline Country & $\mathrm{N}$ & Parties \\
\hline Australia & 252 & Greens $(n=67)$; Labor Party $(n=115)$; Liberal and Nationals combined $(n=70)$. \\
\hline Brazil & 693 & $\begin{array}{l}\text { Partito dos Trabalhadores (PT) and Partido Trabalhista Brasileiro (PTB) } \\
\text { combined }(n=447) \text {; Partido Democràtico Trabalhista (PDT) }(n=44) \text {; Partido da } \\
\text { Social Democracia Brasileira (PSDB) }(n=174) \text {; Partido do Movimento } \\
\text { Democràtico Brasileiro (PMDB) and Partido Progressista (PP) combined }(n=28) \text {. }\end{array}$ \\
\hline
\end{tabular}

Finland 368 Left Alliance, Green League, and Social Democratic Party combined $(n=226)$; Centre party $(n=45)$; Christian Democrats, Swedish Peoples party, National Coalition party, and Basic Finnish party combined ( $n=97)$.

Chile 266 Partido Por la Democracia (PPD) $(n=45)$; Partido Socialista (PS) (n=30);

Partido Demócrata Cristiano (PDC) $(n=55)$; Renovación Nacional (RN) $(n=103)$; Unión Demócrata Independiente (UDI) $(n=33)$.

Germany 795 Die Linke ( $n=43)$; Alliance '90/The Greens $(n=130)$; Social Democratic Party (SPD) $(n=255)$; CDU/CSU ( $n=306)$; Free Democratic Party (FDP) $(n=61)$.

$263 \quad$ K.K.E. $(n=29)$; SYRIZA $(n=40)$; Greens $(n=25)$; PASOK $(n=124)$; New Democracy $(n=45)$.

362 Meretz - the new movement $(n=56)$; Avoda-Meimad $(n=73)$; Kadima $(n=93)$; Likud ( $n=81$ ); HaBa'it Hayehudi - Ichud Leumi, Shas, and Yahadut Ha'Torah combined (Religious-Mafdal, $n=32$ ); Israel Bei'tenu $(n=27)$.

Italy 479 The Italian Marxist and Leninist Party, Workers' Communist Party, the Italian Communist Party, Rainbow Left and the Greens combined $(n=32)$; Democratic Party $(n=226)$; Italy of Values $(n=40)$; UdC, UDEUR, and La Rosa Bianca combined $(n=25)$; People of Freedom Party $(n=136)$, the Movement for the Autonomy, and Northeast League combined $(n=156)$.

227 The Democratic Party, Japan Restoration Party, and Social Democratic Party combined $(n=49)$; The Liberal Democratic Party, New Komeiro, and Your Party combined $(n=178)$.

Poland 548 Democratic Left Alliance (SLD) ( $n=59)$; Samoobrona and Polish People's Party (PSL) combined ( $n=27)$; Civic Platform (PO) $(n=318)$; Law and Justice (Pis) $(n=144)$.

Slovakia 407 KSS, SMER, S.O.S., SDL, and ZRS combined (The Left, $n=171$ ); SLS, SNS, and NationalEthnic combined ( $n=82)$; HZD, KDH, LS-HZDS, OKS, and SKDÚ-DS combined (Conservative Right, $n=154$ ).

292 United Left (UI) $(n=44)$; Spanish Socialist Workers' Party (PSOE) $(n=127)$; Popular Party (PP) (n=121). 
(continued)

Turkey 312 Republican People's Party (CHP) (n=99); Justice and Development Party (AKP) $(n=184)$; Motherland Party (ANAP), Democratic Party (DP), Young Party (GP), Nationalist Movement Party (MHP), and Felicity Party (SP) combined (Other right-wing, $n=29)$.

Ukraine 541 Party of Regions $(n=89)$; Yulia Tymoshenko Bloc $(n=225)$; Lytvyn's Bloc $(n=27)$; Our Ukraine-People's Self-Defense Bloc $(n=200)$.

U.K. $284 \quad$ Liberal Democrats $(n=72)$; Labour $(n=154)$; Conservatives $(n=58)$.

U.S. $317 \quad$ Democratic $(n=210)$; Republican $(n=107)$. 